\title{
GAME THEORY: MINIMISING THE COST OF CAPITAL VS. MAXIMISING THE RETURN OF INVESTORS
}

\author{
Brindusa Tudose \\ Petre Andrei University of Iasi \\ brindusatudose@gmail.com
}

\begin{abstract}
The application of game theory to financial transactions focuses on two categories of stakeholders: users of financing (firms) and providers of financing (investors). The core of game theory consists in the strategy that a partner is able to build starting from the possible decisions of the other partner (each party having opposing interests). In fact, we deal here with a cooperative game in which both opponents seek to maximise their own chances of winning. The article aims to highlight the manner in which mathematical game theory is transposed in the field of corporate finance by balancing the firm's objectives (maximising market value by minimising the cost of raising capital) and the investors' objectives (maximising returns on investments). The intended novelty of this paper lies in developing a model for optimising a firm's financial structure and assessing it in terms of investors' interests.
\end{abstract}

\section{Keywords}

financial structure; optimisation criteria; cost minimisation; profit maximisation

\section{JEL Classification}

G32; C70

\section{Introduction}

The issue of firms' financing has been and continues to be one of the most hotly debated topics for a variety of analysts/researchers, not necessarily finance experts (for instance mathematicians, psychologists, economists). Their works have focused on the optimal mix of the two sources of financing (internal and external), in order to secure the success of major objectives undertaken by management; hence, the financing decision - one of the key decisions in financial management - emerges as a genuine challenge. Most of the theories formulated so far have built analytical frameworks for grounding, understanding and implementing firms' capital structure policies. However, the theories developed have certain limitations, which have posed challenges for further research and experienced varied and wide-ranging debates, with key concepts re-emerging in novel forms (Tudose, 2013).

Inaugurated by Emile Borel (1921) but comprehensively laid out in only 1944 by John von Neuman (a mathematician) and Oskar Morgenstern (an economist), the mathematical theory of games opened up a highly diverse research field. Lately, we have observed increasing interest by finance researchers in reassessing theories of finance against the background of game theory.

With reference to the above, it must be emphasised that certain mathematicians have argued that "mathematical game theory has a broad applicability in the field of financial transactions, yet raises problems related to building specific functions and deliver concrete solutions for various models and classes of determinist or probabilistic financial transactions" (Purcaru, 1998).

The main objective undertaken in this paper is to show how the mathematical game theory is transposed in the field of corporate finance by balancing the firm's 
objectives (maximising market value by minimising the cost of raising capital) and the investors' objectives (maximising returns on investments). When a firm posts minimum cost of capital it is essential to ascertain not only the context that enabled it to achieve this objective but also the extent to which investors were able to achieve their goals too.

\section{Landmarks in specific research}

The adequacy of capital structure represents a major decision for any firm; this is because the decision is founded not only on the need to maximise shareholder returns, but also on the need to ensure the firm's capacity to cope with its competitive environment. The views on the optimal financial structure have varied over time; going beyond the irrelevance theory, it has been recognised that there is a link between capital structure and firm value.

The idea proposed 10 years ago, arguing that "there is no universal theory of the debtequity choice, and no reason to expect one" (Myers, 2001), reoriented research to the level of empirical analyses.

As far as the firm is concerned, its financial structure is designed based on certain criteria (Toma \& Alexandru, 2003) as follows: the firm's rate of return; the cost of raising capital; maximum debt carrying capacity and the flexibility of the financial structure; risk; resource allocation; firm's objectives. Additionally, other criteria may be considered (Tudose, 2006) including: the size of the firm; the weakening of shareholders' controlling power (in case of new share issues); technology risk (which may be offset by leasing equipment); adjusting repayment methods to the firms' financial constraints (certain reimbursement methods may be more convenient even if costlier); loan granting procedures (depending on the urgency of the financing needed, a more expensive alternative may be accepted that provides faster access to funding); loan guarantees being demanded (firms that are unable to deliver the required guarantees must opt for other types of lending, higher priced, but less stringent in terms of collaterals required).

One of the domains of optimization applicability is represented by the financial structure. As the structural elements are variable, they can be combined in such a manner in which the maximization of the firm's value will be attained.

In other words, the optimization of the financial structure can lead to an improvement of the organization and of firms function. By accomplishing this objective favourable premises will be created for both shareholders and creditors; this will have a positive impact on the future development of the firms.

However, when dealing with the optimization issue, in terms of economic theory, must not be adopted a fixed, rigid attitude. As long as the maximization and the minimization are matters of dynamics, the ratio between the useful output and the superior quality input will define the premises of optimization.

When an firm records its maximum level of efficiency, and thus the minimum cost level of the capital (the optimum level), it is compulsory to express the environmental circumstances - exterior and interior environment, financial or of any other nature that allowed the accomplishment of this objective.

\section{Methodology of the research}

Approaching the issue from the firm's perspective, we acknowledge that it is possible to determine the optimal state (based on the cost of raising capital from different sources) by using linear optimisation models. For these purposes, we will build a company finance structure optimisation model, based on the weighted average cost of 
capital criterion. We will simultaneously explain the extent to which investors (financing providers) are able to achieve their objectives.

The value of a financial transaction - V(I,F) - is not perceived in similar fashion by investors (I) and the firm (F); whereas investors aim to maximise the rate of return of their investment, the firm seeks to minimise the cost of raising capital. Because investors and the firm do not act independently, one might argue that both parties will focus on a strategy that will diminish (as much as possible) the effects of the other party's strategy. A financial transaction (investment for investors, capital raising for firms) is optimal (or mutually advantageous, both for the firm and for the investors) if the strategies $m_{10}$ and $m_{20}$ are in place to ensure that:

$$
\max _{m 1} \min _{m 2} V(I, F)=\min _{m 2} \max _{m 1} V(F, I)
$$

Approaching the issue from the firm's perspective, we acknowledge that it is possible to determine the optimal state (based on the cost of raising capital from different sources) by using linear optimisation models.

In order to solve the linear programming problem, I will start from an admissible basic solution (forming a finite set) and will subsequently identify the solutions in order to minimise or maximise a particular function.

\section{Presentation of the model}

The milestones propose are: a) defining the target function (required to perform the optimisation); b) defining the system of equations/inequalities specific to the financial structure to be optimized, in terms of the cost of financing; c) defining the linear optimisation problem; d) solving the problem.

\section{optimisation) \\ Defining the target function (required to perform the} That can be achieved as follows:

$\mathrm{f}(\mathrm{x})$ = weighted average cost of capital $\rightarrow$ minimum, or

$$
f(x)=\frac{C_{p}}{C_{p}+C_{i}} k_{p}+\frac{C_{i}}{C_{p}+C_{i}} k_{i} \rightarrow \min .,
$$

where:

$$
\begin{aligned}
& \mathrm{C}_{\mathrm{p}}=\text { equity capital, } \\
& \mathrm{C}_{\mathrm{i}}=\text { debt capital, } \\
& \mathrm{k}_{\mathrm{p}}=\text { cost of equity capital, } \\
& \mathrm{k}_{\mathrm{i}}=\text { real cost of debt capital (taking into account any tax shields). }
\end{aligned}
$$

As linear programming models only allow linear (minimum or maximum) optimisation functions, we must redefine the optimisation function. Consequently, by using $\boldsymbol{x}_{1}$ to denote the ratio $C_{p} /\left(C_{p}+C_{i}\right)$ and $\boldsymbol{x}_{2}$ for the ratio $C_{i} /\left(C_{p}+C_{i}\right)$, the optimisation function becomes:

$$
f(x)=x_{1} k_{p}+x_{2} k_{i} \rightarrow \text { min. },
$$

where the costs of the two types of capital are known, and $\boldsymbol{x}_{1}$ and $\boldsymbol{x}_{2}$ are the variables (the unknowns). 
Defining the system of equations/inequalities specific to the financial structure to be optimized, in terms of the cost of financing

a) Firms have access to two main types of financial resources, own capital or equity and borrowed capital or debt, respectively; as regards the level of accessibility, it should be noted that a firm can finance itself with $100 \%$ equity, but cannot finance themselves with $100 \%$ debt. The first equation of the system reflects the financial structure:

$$
\frac{C p}{C p+C i}+\frac{C i}{C p+C i}=1
$$

According to the previously employed notation, the equation can be reformulated as follows:

$$
x_{1}+x_{2}=1
$$

b) Own capital - after making an investment financed exclusively by own capital, the level of equity cannot exceed the sum of the initial own capital $\left(C_{p 0}\right)$ and the value of the investment $(I)$. Consequently, the second component of the system will be an inequality:

$$
C_{p} \leq\left(C_{p 0}+I\right)
$$

or

$$
\left(C_{p}+C_{i}\right) \frac{C_{p}}{\left(C_{p}+C_{i}\right)} \leq\left(C_{p 0}+I\right)
$$

or

$$
\left(C_{p}+C_{i}\right) x_{1} \leq\left(C_{p 0}+I\right) .
$$

c) Borrowed capital - after the investment is made - cannot exceed the sum of the initial borrowed capital and the value of the investment (in case the investment was financed exclusively by borrowed capital). The third component of the system will also be an inequality:

$$
C_{i} \leq\left(C_{i 0}+I\right)
$$

or

$$
\left(C_{p}+C_{i}\right) \frac{C_{i}}{\left(C_{p}+C_{i}\right)} \leq\left(C_{i 0}+I\right)
$$

or

$$
\left(C_{p}+C_{i}\right) x_{2} \leq\left(C_{i 0}+I\right) .
$$

From the standpoint of the creditor/investor who seeks to maximise his profit, this transaction is only justified if it involves a premium aligned with the level of risk he is taking. Once loan is agreed, it is argued that both parties (the firm and the investors) have achieved their goals.

d) Borrowed capital - after the investment is made - cannot exceed double the value of own capital (a prerequisite for ensuring the survival of the company and its financial balance).

$$
C_{i} \leq 2 C p
$$

or

$$
\left(C_{p}+C_{i}\right) \frac{C_{i}}{\left(C_{p}+C_{i}\right)} \leq 2\left(C_{p}+C_{i}\right) \frac{C p}{\left(C_{p}+C_{i}\right)}
$$


or

$$
\left(C_{p}+C_{i}\right) x_{2} \leq 2 x_{1}\left(C_{p}+C_{i}\right)
$$

The inequality can be tested by factoring in the known amount of the projected investment; therefore it is not indispensable in defining the system of equations/inequalities.

\section{Defining the linear optimisation problem}

Defining linear optimization problem involves aggregating of the previous relationships shown:

$$
\begin{aligned}
& \left\{\begin{array}{l}
x_{1}+x_{2}=1 \\
\left(C_{p}+C_{i}\right) x_{1} \leq\left(C_{p 0}+I\right) \\
\left(C_{p}+C_{i}\right) x_{2} \leq\left(C_{i 0}+I\right) \\
x_{1}, x_{2} \geq 0
\end{array}\right. \\
& f(x)=x_{1} k_{p}+x_{2} k_{i} \rightarrow \text { min. }
\end{aligned}
$$

\section{Solving the problem}

By incorporating in the model only two variables $\left(x_{1}\right.$ and $\left.x_{2}\right)$, the system may be solved either graphically or by using the primary simplex algorithm or based on the two-phase optimisation method (just as to the matrix of the equation system one may or may not add elementary transformations to construct a unit matrix) (Reitano, 2010).

\section{Limits of the model}

Minimising the cost of the firm's equity capital must not be viewed in absolute terms, must not represent an objective in itself; rather this goal must be aligned with a broader focus on improving the financial structure and maximising the firm s value.

The financial structure of a company which does not pay dividends (zero cost of equity) cannot serve as a reference for optimisation. A firm which pays a high number of dividends does not necessarily have an unfavourable financial structure (Onofrei, 2009). The concerns regarding increasing the rate of return on equity do not derail the company from the path of optimising its financial structure. Due to their higher return, a company's shares will be more attractive to investors and the increased share price will have "have a positive effect on the market value of the company" (Vernimmen, 2009).

Nor can the cost of debt capital be considered as an absolute reference. Each creditor requires a target rate of return in exchange for providing access to his financing source. Considering that investors (creditors) have several options for investing their capital, they will opt for the investment type offering a risk premium, the rate of return in excess of a risk-free return rate.

The model we developed is based on a single-criterion optimisation. In practice, the cost of capital is not the sole determining factor in financial decisions. Building a model that should enable a multi-criterion optimisation of the firm's financial structure will constitute a future focus of research for us. 


\section{Conclusions}

The defined model reinforces the claim that the mathematical game theory has an extensive area of application in the field of financial transactions, at the same time overcoming the issues that may arise in constructing specific functions; the concrete solutions for the function $f(x)$ : the weighted average cost of capital $\rightarrow$ minim will enable the determination of solutions for the optimisation function of the type $\max _{\mathrm{m} 1} \min _{\mathrm{m} 2} \mathrm{~V}(\mathrm{I}, \mathrm{F})=\min _{\mathrm{m} 2} \max _{\mathrm{m} 1} \mathrm{~V}(\mathrm{~F}, \mathrm{I})$. The equilibrium state of the game is defined by the finite set of strategies identified for each actor.

The purely financial premises that constitute the base for achieving an optimum capital structure are: knowing the cost of the financing sources and the fluctuation of the interest rate; knowing the typology of the enterprises because, depending on their dimension, the organisations have access to different sources of financing; knowing the financing needs of the enterprises; knowing the weight of participation for different financing sources at the enterprise level; knowing the financial environment at a macroeconomic level and of the financial-monetary policies - fiscal, monetary, credit, income - promoted in a given length of time; we also include here the degree of development and functionality of the capital markets because through them the enterprises can attract resources corresponding to various time horizons; knowing the behaviour of the parties that participate on the financial market and their willingness to take risks; knowing the psychological implications of indebtedness, because the financial structure of an enterprise will be greatly influenced by the attitude of the financial decision-makers regarding the possibility of falling into debt.

\section{References}

Myers, S. (2001). Capital structure, The Journal of Economic Perspectives, 15(2), p. $81-102$.

Onofrei, M. (2009), Guvernanța financiară corporativă, București, Editura Wolters Kluwer.

Purcaru, I. (1998), Matematici financiare, București, Editura Economică.

Reitano, R. (2010), Introduction to Quantitative Finance, Cambridge, MIT Press.

Toma, M., Alexandru F. (2003), Finanțe și gestiune financiară de întreprindere, București, Editura Economică.

Tudose, M. B. (2006), Gestiunea capitalurilor întreprinderii. Metode de optimizare, București, Editura Economică.

Tudose, M. B. (2013), "Real effects of the firm financing and risk management”, in Abordări conceptuale și metodologice ale proceselor economice, București, Editura Academiei Române.

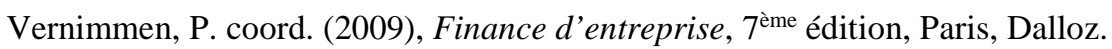

